\title{
The Corps Disease: Brucellosis and Its Historical Association with the Royal Army Medical Corps
}

\author{
Maj D J Vassallo \\ FRCS(Ed), RAMC \\ Senior Registrar in Surgery \\ Royal Army Medical College, Millbank, London, SWIP 4RJ
}

SUMMARY: Brucellosis (also known as Malta, Mediterranean or Undulant Fever) has aptly been nicknamed the Corpo

Disease because of the major role played by the Royal Army Medical Corps in elucidating its nature and discovering it든 mode of spread, thus leading to its prevention and eradication. This history of brucellosis, incorporating a completop

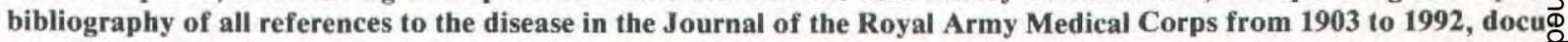
ments the fascinating story of this association.

\section{Introduction}

Brucellosis has almost certainly plagued peoples of the Mediterranean littoral and further afield from time immemorial, though its existence as a separate entity was only recognised with the discovery of its causative organism by Bruce in 1887. British troops were first stationed in Malta in 1798, aiding the Maltese to oust the French from the island during the Napoleonic Wars, and during the nineteenth and early twentieth centuries this illness wreaked havoc amongst the soldiers and sailors of the Malta Garrison. This generated tremendous investigative efforts by doctors of the Army Medical Services, such as Matthew Louis Hughes, James Crawford Kennedy, William Horrocks and David Bruce, as well as the Maltese doctor Themistocles Zammit. This culminated in the successful efforts of the Mediterranean Fever Commission (mainly drawn from the ranks of the RAMC) between 1904 and 1907, which identified the Maltese goat as the reservoir of infection, thereby leading to effective preventive measures.

The Journal of the Royal Army Medical Corps came into being in 1903, and two of its first editors (Bruce 1904-1908, Horrocks 1908-1940) were eminent in the fight against brucellosis. As a result, the Journal effectively became the mouthpiece through which each stage of this epic fight was broadcast to the world, publishing many important original papers and reproducing seminal contributions from other sources when necessary. Thus this history of brucellosis, incorporating a complete bibliography of all references to the illness in the Journal from 1903 to 1992 , should be of special interest to medical historians and also to those members of the RAMC intrigued by what has so appropriately been nicknamed the 'Corps Disease'.

\section{History \\ Prior to 1903}

Bruce, in his first editorials in the Journal of the Royal Army Medical Corps after his appointment as editor in 1904, summarised the history of brucellosis (then variously known as Malta, Mediterranean or Undulant Fever) up to that time, with special reference to its relation to the RAMC. The first paper on brucellosis by a

British Military Surgeon was that in 1863 by Assistan $\vec{P}$ Surgeon Jeffrey Allen Marston, who gave a very accu $\overrightarrow{\text { ज }}$ rate description of the illness in troops invalided to Malt $\stackrel{\omega}{\sigma}$ during the Crimean War, calling it "Mediterranea Remittent (or) Gastric Remittent Fever", His last cas history was a poignant depiction of his own suffering from the disease, noting the irregular type of fever, th $\omega_{\infty}$ languor and weariness, the muscle and joint pains, tho gastro-intestinal symptoms and the long duration of ness (1) (Fig 1). In 1879, Surgeon Major H Veale, 赵s sistant Professor of Military Medicine at the Ar.th Medical School, reported from the Royal Victoria He pital at Netley on Southampton Water on fever patiक्ष巾: invalided from Gibraltar, Malta and Cyprus, poin की out the distinctions between this fever and malaria, क्षा teric fever and relapsing fever (2).

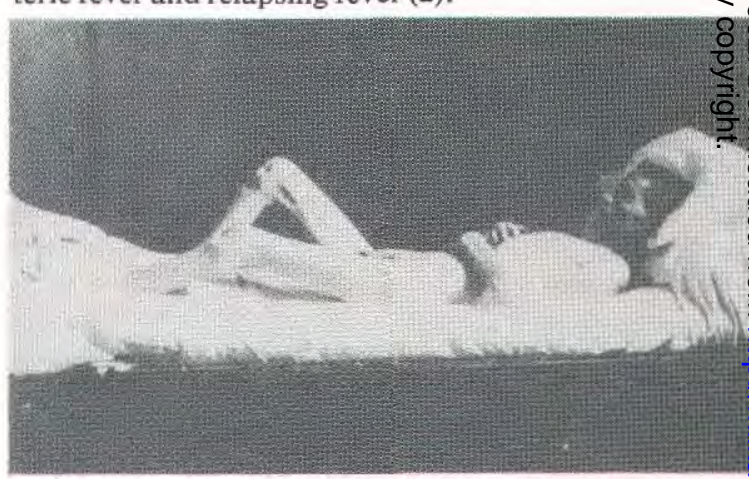

Fig 1. "Malta Fever Patient"; by David Bruce.

Acknowledgement to Wellcome Institute Library, London.

Surgeon Captain (later Sir) David Bruce, while based in the Station Hospital in Malta's capital city, Valletta from 1884 to 1888 , carried out his researches into Malt Fever, reporting that it was attacking several hundres soldiers and sailors every year, their average length of stay in hospital in Malta being 85 days, with many being invalided to England. On July 9, 1887 he isolated th specific organism responsible for the disease from the spleen of a victim, going on to prove its causal role bN isolating it from splenic cultures from seven other fatan cases, and by animal experiments (3-5). In 1893 Bruce 
named the organism 'Micrococcus melitensis' from the Roman name for Malta, Melita (the Honey Isle). The classic monograph by Surgeon Captain Matthew Louis Hughes in 1897 on "Mediterranean, Malta or Undulant Fever" after his six year tour of duty in Malta contained everything known on the subject up to that date and included a complete bibliography (6). In the same year, Professor (later Sir) Almroth E Wright (Professor of Pathology at Netley) and Surgeon Major (later Sir) David Semple (Assistant Professor of Pathology) successfully applied the method of serum diagnosis, enabling clinicians to differentiate Malta Fever from enteric, malarial and other fevers (7-8).

\section{Prologue 1904-1905}

The first article relating to Malta Fever in the Corps Journal was in 1904 by Lieutenant James Crawford Kennedy who was stationed in Malta from 1901 to 1906. Kennedy spent most of this period in charge of the Acute Fever Wards at the Station Hospital, Valletta (previously the Holy Infirmary of the Knights of St John and now converted into the Mediterranean Congress Centre) and suitably enough his article described a classic case history in a soldier with slight but long-continued fever and severe pains localised to the shoulder joint (9). Next follow the first editorials by Colonel (later Sir) David Bruce, describing the history of the illness, its clinical presentation, its geographical distribution worldwide and in Malta, with full details on the Micrococcus melitensis and speculation on the mode of infection (1012). At this stage in time, no one knew the source of infection or the method of spread. The prevailing view was that the disease might be transmitted to man by mosquitoes or other blood-sucking insects. Further papers reflect the concern of doctors in the Malta Garrison at the high incidence of Malta Fever in the civil and military population, and in the army and naval hospitals (13-19), together with a case report from England (20).

Already, the feeling was that "Mediterranean Fever may be considered in a great degree as the special property of our Corps" (14). With hindsight the unintentional irony of this comment becomes apparent, for many soldiers and sailors, in hospital for other reasons, caught Mediterranean Fever whilst under medical care - from the goats' milk which was prescribed for them!

\section{The Mediterranean Fever Commission 1904-1907}

The Mediterranean Fever Commission (MFC) was formed in 1904 by the Royal Society at the request of the Secretary for the Colonies, Mr Alfred Lyttleton, because of the great concern about the prevalence in Malta of Mediterranean Fever. Its working members represented the Army, the Navy and the Civil Government, and initially consisted of Colonel D Bruce RAMC as president, together with Major W H Horrocks RAMC, StaffSurgeon E A Shaw RN, and Dr T Zammit MD, Board of Health, Malta, assisted by Captain J Crawford Kennedy RAMC (appointed late in 1904), and by Staff-Surgeon R
T Gilmour RN (who placed his spare time at the serviee of the Commission in 1904 and 1905). Later membess included Lieutenant-Colonel A M Davies RAMC, Dr W H Eyre (Bacteriologist to Guy's Hospital), Majors J McNaught, T McCulloch and J C Weir RAMC, Dr R Johnstone (Local Government Board), Staff-Surgeon $\bar{T}$ H A Clayton RN, and Fleet-Surgeon P W Bassett-Smi角 RN.

The work of the Commission was eventually pu lished in seven volumes of Reports by the Royal Society (21), almost all of which were then reprinted by special permission in the Journal of the Royal Army Medicy Corps.

The Reports reprinted in the Corps Journal may grouped under two headings: Experimental arod Epidemiological, and are excellent examples of is vestigative medicine at its best. The main aim of the Ex periments (22-37) was to determine the chain $\overrightarrow{a f}$ transmission of the disease, and the speed with which the correct conclusions were reached show what can be do with a concerted all-out effort and a little bit of luck! The Epidemiological Reports deal with the prevalence $d$ Mediterranean Fever amongst British troops in Malta 97 1905 (38-42) and amongst the population of Gibraltar (43).

\section{Naval Entomologists}

Royal Navy Surgeons Edward H Ross (the brothe of Sir Ronald Ross) and G Murray Levick were both कृe keen entomologists, and in the course of their shipbofing Mediterranean travels aboard the cruiser HMS Bamcaster in 1904-1905 they carried out numerous ex ments and investigations into blood-sucking insects $84 \$$ 45 ). They strove very hard to prove their hypothesis Shat $^{2}$ Mediterranean Fever was mosquito-borne, just likeondlaria. Dr T Zammit in Malta, who had been cor sponding on the subject with Sir Ronald Ross, helped them out by performing many bacteriological studies for them.

\section{Serendipity}

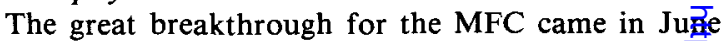
1905 when Dr (later Sir Themistocles) Zammit, the onily Maltese member of the MFC, successfully incriminated the Maltese Goat as the animal host of Micrococctis melitensis, by his discovery that the blood of expenmental goats reacted to Mediterranean Fever using agglutination test, and by his isolation of the Micrococcus melitensis in pure culture from goals' blood. It was only a temporary shortage of monkess upon which to experiment that led to goats being piocured for the 'in vivo' work - truly a case of 'serendipidity': "These two experiments led me to the belief that goats are susceptible to Malta Fever, and that the disease may be spread to human beings by goats" (4) This seminal contribution is an editor's dream: only two pages long! Previously goats had been regarded As immune because injection of cultures into them seemed 
to have no effect. However, when Dr Zammit found that their serum aggiutinated the organism, he concluded that though it had caused no symptoms the organism must have lived and multiplied in the tissues - a condition later recognised as "inapparent infection". His colleague Major W H Horrocks (later to become editor of the Corps Journal) showed that some of the goats in every herd examined were affected by Malta Fever, and confirmed that M.melitensis was exuded in the milk of these infected goats (47). This discovery was to have worldwide repercussions, as well as having serious financial implications for Maltese goatherds, for the hardy Maltese goat was renowned for its milk-producing qualities, and had been exported throughout the British Empire.

\section{Controversy and Vexed Milkmen}

As is so frequently the case in medical discoveries, controversy was to dog the footsteps of researchers in brucellosis. Zammit's contention that infected goats' milk might be the mode of transmission of infection was hotly disputed by Surgeons E H Ross and G Murray Levick who were still pursuing mosquitoes around the Mediterranean (48). They claimed to have drunk such milk without coming to harm, and they issued a challenge to the milk marketing authorities, offering to drink naturally infected milk to disprove Zammit's findings. However their offer was refused, and they could not stay in Malta long enough to obtain for themselves naturally infected milk!

The findings of Zammit and Horrocks were corroborated by further investigations (49) which revealed that up to 50 per cent of the 20,000 goats in Malta were infected and that some 10 per cent were actually excreting the organism in their milk.

In recognition of their strenuous exertions and the importance of their research, and to encourage them for the forthcoming struggle to implement effective preventive measures, the new members of the Mediterranean Fever Commission were feted out to dinner by the RAMC in April 1906 (50).

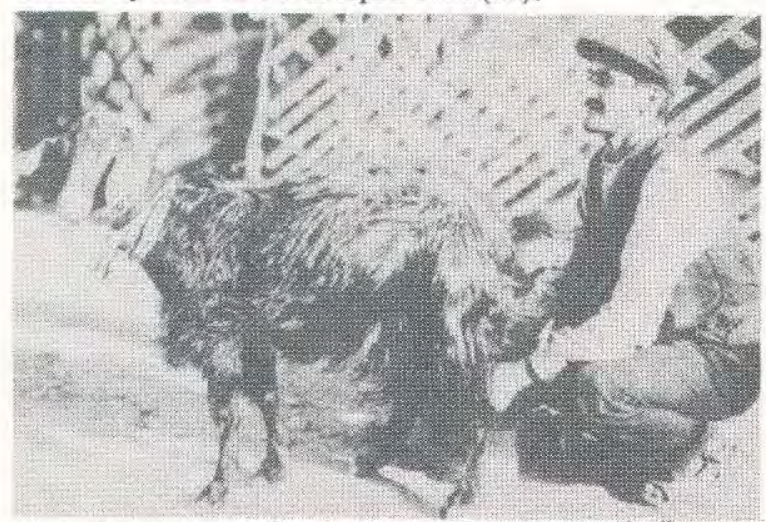

Fig 2. "Goat-Herd Milking, Malta"; by David Bruce.

Acknowledgement to Wellcome Institute Library, London.
The Maltese goatherds and milkmen, who for centuries had driven their herds through the streets to deliver their milk fresh (and unadulterated!) on the doorsteps of their customers (Fig 2), saw their livelihood 3 apparently threatened. They rose up in protest and went응 on strike from 15 May to 1 June 1906, plastering placards listing their grievances all over Malta. AO translation of this placard headed "No More Milk!!!! ? We cannot stand it any more! We cannot do any more! "⿱⿱⺌冖コ口 and signed "The Vexed Maltese Milkman" was publisheto in the Corps Journal (51). A copy of the original placardo in Maltese is held in the RAMC Muniment Collection.

The strike coincided with the institution of vigorous $\cong$ Public Health measures in May 1906, with the banningos of goats' milk from the diet of the regiments and from $\vec{\circ}$ military and naval hospitals, and its substitution by tinned milk imported from England. The first RAMC $\vec{\omega}$ unit to discontinue goats' milk was the Forrest Hospital on the 18th May 1906. The milkmen's strike proved distinctly useful in getting the use of goats' milk? discontinued, for as the goatherds themselves had $\vec{\omega}$ stopped supplies, they could hardly complain when theiro customers, having made other arrangements, refused toc go back to them.

Full use was made of the Regimental system authority in enforcing the ban on goat's milk. Thio Major T McCulloch, on behalf of the MFC, delivere lecture on the 1st June 1906 on "The Means ब Prevention of Malta Fever" to all Quartermasteg Quartermaster Sergeants and Regimental Sergearite Majors of the Garrison at the Office of the Colonel $\frac{8}{0} \mathrm{~N}$ the General Staff, actively enrolling them in the fis against Malta Fever (51). A copy of this lecture is heldọn? the RAMC Muniment Collection.

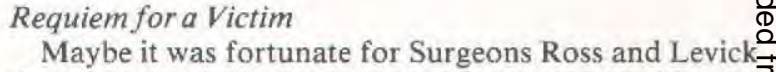
that they could not obtain infected goats' milk, for Malta Fever was no respector of rank or occupation. Inevitably, many of the hospital staff caring for it victims or investigating it fell victim themselves to its ravages before the mode of infection was discovered, sometimes succumbing to it in those pre-antibiotic days. In 1905, Colonel W O Wolseley, Principal Medical Officer in Malta from November 1903 to June 1905, fell迎 ill with the disease. Despite being invalided home to Tilbury, he died on the day of his arrival in England, thereby earning the unwanted distinction of being the most senior British officer ever to die of brucellosis. Heᄋ was held in great esteem (52-56), and a photograph of the 3 memorial brass erected by the Officers of the Corps ino his memory appears in the Corps Journal (55). This large brass was erected in the Royal Army Medical College (54), but it is now prominently displayed in the RAMCN Museum. Another account describes the unveiling by the Governor of the Island of the memorial tablet erected by 
Colonel Wolseley's wife at the Barracca Church in Malta' (56).

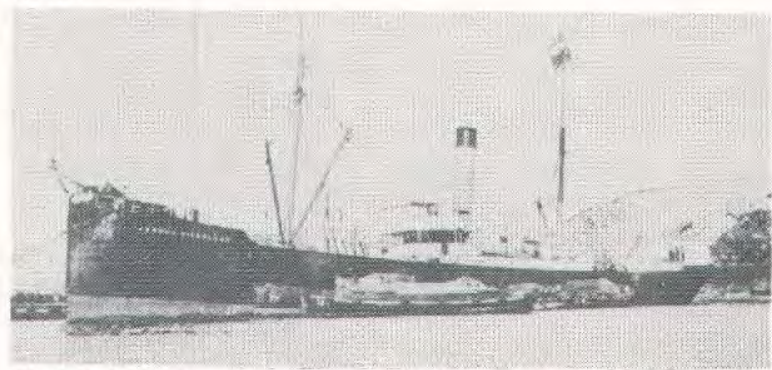

Fig 3. S.S. Joshua Nicholson (in Valletta Harbour, Malta).

Acknowledgement to Wellcome Institute Library, London.

\section{S.S. Joshua Nicholson (Fig 3)}

Just as the mode of transmission of cholera was elucidated by John Snow in the famous Broad Street Water Pump epidemic of 1824 in London, so a similar fortuitous epidemic of brucellosis, this time aboard ship, was to figure in the history of brucellosis. The first intimation of this epidemic was published in the Corps Journal in 1906 as a short letter to Bruce from Dr N Armand Ruffer, Maritime Quarantine Officer in Eygpt (57). The Corps Journal published further details of the epidemic as they became available (58-62). The epidemic was later fully described by Staff-Surgeon Clayton RN (63), and subsequently elaborated on by H H Scott (64).

The merchant vessel S.S. Joshua Nicholson, trading between Antwerp and Egypt, anchored at Malta for one day in August 1905. It took on board 65 milch goats bound for Washington, where the Bureau of Animal Industry of the United States Department of Agriculture had decided to import Maltese goats, good milk producers, in order to encourage goat keeping amongst peasant immigrants from Southern Europe. En route back to Antwerp, practically the whole of the ship's crew drank the goats' milk unboiled, and within weeks all those who had drunk the milk were struck down with Malta Fever. This gave the clearest possible proof of the connection of Malta Fever in man with the Maltese goat.

\section{Goats and Fever on "The Rock"}

In addition to the epidemic of Malta fever on board S.S. Joshua Nicholson, further proof of the connection with goats' milk was provided by Major Horrocks in his new role as Sanitary Officer in Gibraltar in 1907. He made the important observation that, whereas in 1883 all the goats on the Rock were Maltese and Malta Fever was then very common, the disease had disappeared in 1904 with the cessation of importation of Maltese goats due to the withdrawal of grazing passes and the increase in the cost of shipment, and their replacement by Spanish goats (43).

\section{Victory}

Colonel Bruce gave a complete update on the epidemiology of Malta Fever, summarising all the findings of the MFC, to the Epidemiological Society in
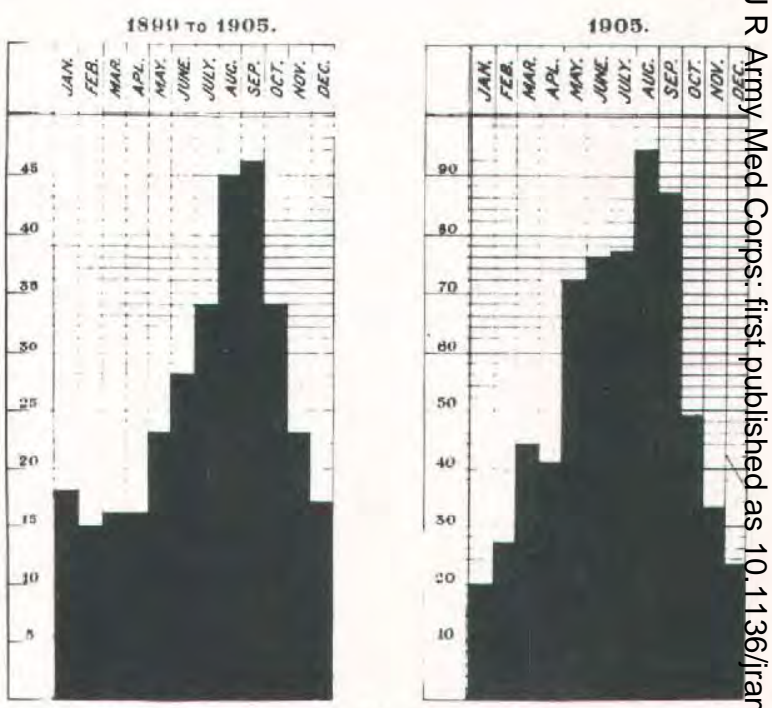

Fig 4. "Prevalence of Malta Fever in the Garrison, per 1,000 Servicemen, 1899 to 1905 '; by David Bruce. Acknowledgement to Wellcome Institute Library, London.

Feb 1907 (65). A similar resumé was presented by Flegt Surgeon P W Bassett-Smith RN to the United Servi Medical Society in December 1907 at the Royal Arịyo Medical College, Millbank (66).

The most striking feature of each presentation was $\vec{\phi}$ e् contrast shown between the incidence of Malta Fe before and after the banning of the supply of goats' mgik in June 1906 to the Garrison and Military Hospitals $\otimes^{\mathrm{f}}$ Malta (Fig 4-5), the cases of Malta Fever rapidyyco dropping to one-tenth of what would have been theirn
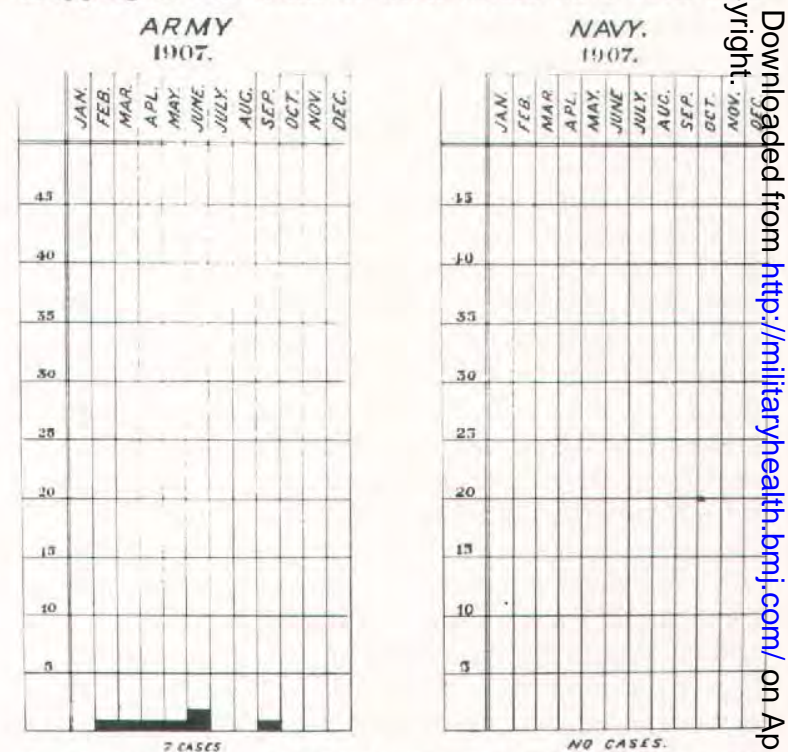

Fig 5. "Prevalence of Malta Fever, per 1,000 Servicemen, aftêत. Banning of Goats' Milk"; by David Bruce.

Acknowledgement to Wellcome Institute Library, London. 


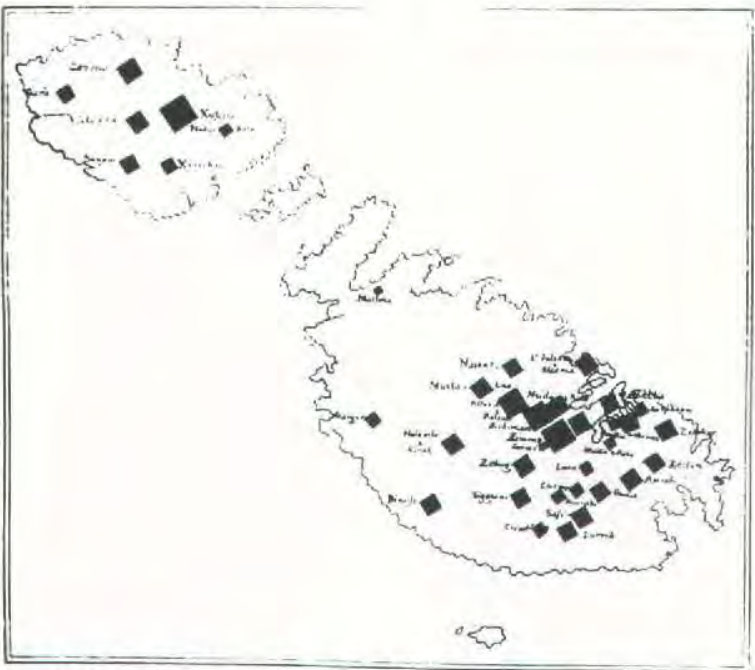

Fig 6. "Map of Maltaq and Gozo, Showing the Distribution of Malta Fever in the Various Towns and Villages of the Two Islands"; by David Bruce.

Acknowledgement to Wellcome Institute Library, London.

normal number. By 1908, Malta Fever had been almost eliminated amongst the troops, whereas the civilian population (who for generations had watched goats being milked on their doorstep and could not accept the fact this milk might make them ill) continued to drink goats' milk, and showed no corresponding fall in the incidence of the disease - providing a striking control test to the experiment on the garrison (Fig 6). Thus, in 1918 , Colonel William Thorburn was able to make the telling comment in his review of war surgery in Malta and the Mediterranean during the Great War that "Malta Fever ... is now practically unknown among the British, who use only tinned milk, but it is still endemic among the civil population" (67). In fact, Malta Fever was to remain rife amongst civilians for many years, its incidence only beginning to fall when the Government of Malta established a Goats' Milk Pasteurisation Centre under the management of Stanley Barnes in May 1938 (68). It was only when the sale of raw milk was banned throughout Malta and milk pasteurisation became compulsory in 1957 that the disease was conquered amongst the civil population, after which time it became limited to dairy workers and to persons eating raw goats' milk cheeselets, "gbejniet", a popular local delicacy (69).

The Royal Society's efforts were duly acknowledged in 1908 in the House of Commons (70). In the same year, Colonel Bruce resigned as Editor of the Journal due to his being posted back to Uganda as Chairman of the Royal Society's third Sleeping Sickness Commission. His place was taken by Major W H Horrocks (71).

Captain James Crawford Kennedy ended his tour of duty in Malta in October 1906 (72), and two years later, on 17th October 1908, he was awarded the Medical
Faculty Gold Medal by the University of Edinburgh for the excellence of his MD thesis on "Malta Fever" (73). This thesis was based on research on the tremendous number of patients with Malta Fever under his care whilst officer in charge of the Acute Fever Wards in the Station Hospital, Valletta, a unique and unrepeatable experience. During the ceremony it was noted with pride that both Colonel Sir David Bruce and Captain Kennedy were graduates of Edinburgh University, and that "their success had practically added the services of a whole $\bar{C}$ regiment to the strength of the garrison station of Malta." Individual copies of this thesis are held in the $\frac{\bar{\omega}}{7}$ University of Edinburgh, in the Library of the Royal $\stackrel{\mathbb{2}}{2}$ Army Medical College, Millbank, and in the RAMC \& Muniment Collection.

The victory over this dread disease was celebrated in grand and merry style in Malta at the Royal Army Medical Corps Ball held on the 10th March 1909 in the Great Ward of the Station Hospital, Valletta (Fig 7), which had been bereft of patients by that simple measure of banning goats' milk. As a newspaper reporter wrote in his account of the Hospital and the Ball: "the darkest $\boldsymbol{\infty}^{\circ}$ days of its existence will scarcely have compared with the period, fresh in memory, when the capacity of the building with its rows and centre rows of beds - and $\$$ army of doctors, nurses and attendants, was stip insufficient to accommodate and attend to the number of those who fell an easy prey to the ravages Mediterranean Fever, All this is happily a thing of tla past." (74). This "memorable and red-letter day in the annals of the Corps in Malta" marked "the success of af investigation which, by the eradication of Malta feve has permitted the transformation of perhaps the larges hospital ward in the world into that of a dazzling and brilliant ballroom" (75).

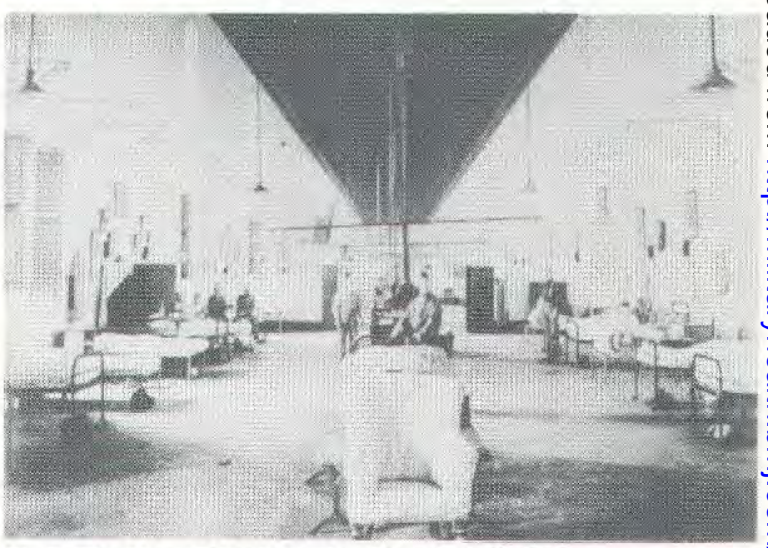

Fig 7. The Great Ward, Station Hospital, Valletta.

Acknowledgement to Wellcome Institute Library, London.

\section{Epidemiology}

In those heady days of the British Empire before the Great War, there were ample opportunities for RAMC doctors to pursue epidemiological researches around the 
world on Mediterranean Fever, in addition to the ongoing research and case studies in Malta (50,76-95).

Surgeon E H Ross, after a hectic three weeks in Egypt in 1905, reported on the prevalence of Mediterranean Fever in Port Said, seeking evidence to prove that Malta Fever was mosquito-borne (96). A later report of his in 1911, after he had become Health Officer there, and an older and wiser man, gave details on the elimination of the illness from Port Said by the eradication of infected goats (97). In 1906 Lieutenant-Colonel C Birt and Dr Strachan both reported that they had found Malta Fever to be endemic in the Orange River Colony in South Africa and that goats' milk was much used in the district (98-99), and in 1909 they updated their report confirming the presence of a widespread epizootic of Malta fever amongst the goats of South Africa (100). Colonel Bruce, during his work in Uganda in 1909 with the Sleeping Sickness Commission, investigated the local disease 'Muhinyo', proving it to be Malta Fever (101). There were also a number of case reports from Gibraltar (102-103), from the Orange River Colony (104), the Blue Nile (105) and Sudan (106-108).

\section{"Poor Maltese Goat . . !"}

It occurred to Captain Crawford Kennedy that the Reports of the MFC might prove rather heavy going for some readers of the Corps Journal, so he supplied some delightful humorous quotes from local newspapers reflecting the strongly held beliefs of the civilian population on the innocence of the Maltese goat (109). Two will suffice here:

"Why, instead of inventing Maltese fevers, do they not suggest to their countrymen not to overtire themselves under the scorching rays of the sun for hours and hours playing the Savage game called Rugby?";

"Poor Maltese goat! What a war has been waged against her! How she has been humbled all over the world as a filthy and poisonous animal! ..."

Several "Notes from Malta" in the Corps Journal $(83,110)$ mention in passing the work on Malta fever, but really are much more interesting for the picture they paint of a Garrison in peacetime, whose concerns were understandably more on recreation than on illness.

The ongoing controversy on the goats' role in the transmission of Mediterranean Fever was however to fuel a vigorous correspondence in local newspapers and international journals for several years (111), with occasional literary gems such as the satirical poem "Bruce and the Microbe" (112), two of whose eight stanzas run as follows:

\section{David found a little Germ -}

Its name, of course, you know;

For everywhere that David goes

That name is sure to go.
He found it in a Spleen one day,

And raised a cultured stock;

"With you," he said "I'll demonstrate

The postulates of Koch.."

\section{David knew a little Boat}

That was for New York bound,

With five-and-sixty little goats

That yielded milk all round.

And in the milk that microbe lurked.

(Hence David would forbid it),

And when the men got sick and ill,

"Twas germs," he said, "that did it."

\section{Brucellosis and cows}

In 1914 Major J Crawford Kennedy sounded warning $\vec{\circ}$ bells when he drew attention to the possibility of a melitensis infection in cows in England (113) after $\vec{\sigma}$ discovering that the milk and serum of certain? apparently healthy London cows agglutinated the Micrococcus melitensis. This agglutination had already been noted in passing by Major Horrocks in $\vec{\omega}$ Gibraltar (43). Subsequent research, especially aftero the distraction of the First World War, clarified thec relation of contagious abortion in cattle 和 Mediterranean Fever, with the realisation that theo causative organism, Bacillus abortus, isolated December 1895 by Professor L F Benhard Bang (市O outstanding Danish veterinary pathologist a add bacteriologist) was actually a separate strain of t增然 Brucella genus (114-117). This led to it being renamgen Brucella abortus. An editorial by Colonel Sir Williaung Horrocks in 1938 (118) reviewed the results off? epidemiological investigations in France, fu describing the differences between the melitens abortus and suis strains of Brucella (responsible for the caprine, bovine and swine types of Undulanto Fever).

\section{Literature reviews}

Over the years, the Corps Journal has published several book reviews or abstracts from articles on brucellosis published in other journals. As the diseases. was gradually recognised as having a very wide geographical distribution, one can trace the progression of the fight against brucellosis in specific countries, e.g $\frac{\vec{D}}{2}$ India (119), Tunisia (120), England (121), Algeria (122 123), France (124-125), South Africa (126-127), and $\vec{P}$ Italy (128). Thus one comes across the appeal for the illness to be renamed "Bruce's Septicaemia (129). mention of the first cases of Malta Fever recorded from? German South-West Africa (130), and research on the Maltese Goat itself (131). There are also reviews on the influence of Tuberculosis on the development of Brucella infection (132), and on Brucella abortus. infection in man (133-136), which was eventuallos recognised as a major cause of undulant fever in many̆ 
parts of the world, and a couple of case reports (137. 138). Of most interest perhaps is an extensive review of $\mathrm{H}$ Harold Scott's monumental work in two volumes, "A History of Tropical Medicine"', based on the Fitzpatrick Lectures 1937-1938 delivered before the Royal College of Physicians of London. This work honours the memory and details the medical achievements of many distinguished officers of the RAMC in relation to the history of tropical medicine. It includes a comprehensive chapter on Undulant Fever and a biography of David Bruce (139).

\section{Let us now praise famous men ...}

a. Obituaries. Major J C Weir became the first member of the MFC to die, succumbing to cholera in India in December 1909 (140). The end of an era came with the deaths of Major-General Sir David Bruce on 27 November 1931 in Artillery Mansions, Victoria, London (within four days of the death of his wife, Lady Mary Elizabeth Bruce, who had so ably supported his work throughout their lives) and Colonel Sir William Horrocks on 26 January 1941. Both men had figured prominently in the history of brucellosis, yet, as their obituaries so ably demonstrate (Bruce's obituary incidentally was penned by Horrocks), this starring role had only been one aspect of their multi-faceted and much-honoured careers and lives. They had both been prolific and gifted research workers as well as being profoundly happy in their own married lives. They had both been editors of the Journal of the Royal Army Medical Corps, one of them for an unrepeatable 32 years spanning two world wars, and both were dedicated to the Journal as well as to the Corps itself (141-143).

b. Memorials. Bruce was one of the Corps' greatest pathologists, for he not only discovered the causative organism of Malta Fever (since 1920 named Brucella melitensis in his honour), but he also performed sterling work on the Sleeping Sickness Commission (for instance, demonstrating that nagana, a fatal disease of cattle, was due to a trypanosome (later named T.brucei) conveyed by the bite of the tsetse fly, and later elucidating with Castellani the causative role of $T$. gambiense in sleeping sickness in man). He was Assistant Professor of Pathology at Netley from 1889 to 1894 , and later investigated dysentery, enteric fever, and, during the First World War, as Commandant of the Royal Army Medical College, he chaired War Office Committees on trench fever and tetanus.

It was therefore very fitting that the British Military Hospital at Mtarfa, Malta was renamed "the David Bruce Military Hospital" in 1951 in honour of his work on undulant fever (144), and that the Army Vaccine Laboratory, 'in lineal descent of those at Netley in which he worked and those of the College which he subsequently commanded', was renamed the David Bruce Laboratories in the same year (145-147). The Corps Journal also saw fit to reproduce a letter written during the siege of Ladysmith in 1902 by Lady Bruce to $D$ her brother (148).

The David Bruce Military Hospital was rebuilt in 1969-70, and was formally re-opened and renamed as "the David Bruce Royal Naval Hospital, Malta" in ${ }_{\varrho}^{\mathbb{\Phi}}$ October 1970, to coincide with the handing over of the old Royal Naval Hospital at Bighi, overlooking the Grand Harbour, to the Malta Government (149).

On 25th June 1980, the 75th anniversary of $\mathrm{Sir}$ Themistocles Zammit's discovery of the germ of undulant fever in the blood of a goat, the restored old? Laboratory where Bruce, Horrocks, Kennedy, Zammit $\frac{\bar{\sigma}}{\overline{0}}$ and the other members of the Mediterranean Fever $\frac{\text { s }}{\widetilde{D}}$ Commission had carried out their research was opened to the public "as a revered trysting spot for ourc" colleagues from overseas during their medical $\vec{\circ}$ pilgrimages to Mediterranean lands" (150).

c. Special Centenary Issue. The centenary of Sir Davide Bruce's birth (on 29 May 1855) was commemorated by a? special Centenary Issue of the Corps Journal in April 1955, containing several relevant or speciallyọ commissioned articles in appreciation of him and his work (151-156).

d. Bibliography. The Librarian of the Royal Army Medical College, M Davies, painstakingly compiled bibliography of the work of Sir David Bruce for theo Centenary issue (155), and followed this with another onSir William Heaton Horrocks (157). The occasion of theO Clinical Meeting of the British Medical Association \$n? Malta in 1969 prompted a commemorative article a d another bibliography (158) this time belatedly marki 9 . the centenary in 1967 of the birth of Surgeon-Captaines Matthew Louis Hughes, who coined the term "Undulaint" Fever", and whose classic monograph in 1897 won $\vec{f}$ r. him a permanent place in medical history (6).

e. Philately. The only two postage stamps in the worldo referring to brucellosis were issued by the Malta Postő Office on the 14th April 1964 to commemorate an international congress held in Malta by the Food and $\overrightarrow{0}$ Agriculture Organisation of the United Nations to 3 discuss the control of brucellosis in the Mediterranean? countries. The $2 \mathrm{~d}$ stamp features portraits of Sir David? Bruce and Sir Themistocles Zammit, and the 1s 6d stamp depicts a goat and a microscope of the sort used by Bruce and the other members of the MFC, symbolising the fight against the disease (159-160).

\section{Epilogue}

a. Vella. Recent years have seen a renewal of the links between Malta, brucellosis and the Royal Army Medica Corps and its Journal through the person of Colone? Ethelwald (Wally) Vella, now retired (Fig 8). Of Maltese origin, ever entertaining, knowledgeable and instructive, Colonel Vella has had a lifelong interest in brucellosis:- $\frac{D}{0}$ As Assistant Professor of Army Pathology (and therefore a direct successor of Bruce), and as Honoraryo Assistant Editor of the Corps Journal from 1970 until hà 


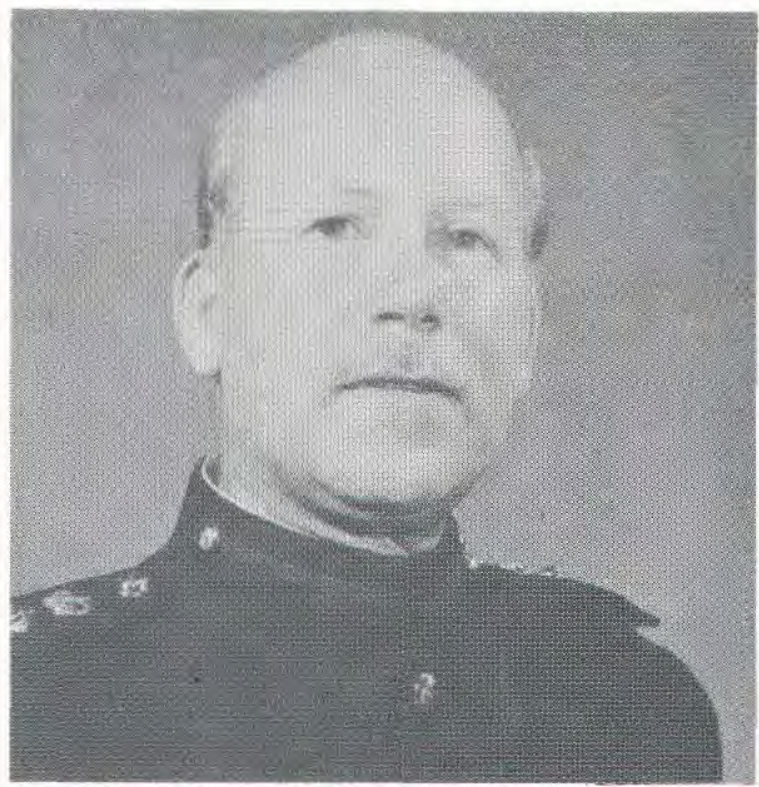

Fig 8. Colonel Ethelwald E Vella L/RAMC.

retired in 1985, he was a prolific and gifted writer, contributing many articles to the Corps Journal, including several on brucellosis and an excellent biography of Bruce (161-164). He brought new insights into the history, aptly nicknaming brucellosis "the Corps Disease" (164), highlighting the relationship between the British Army Medical Service and Malta Fever (165), and bringing Bruce 'to life' again for us.

b. RAMC Muniment Collection. The historical archives of the Royal Army Medical Corps were previously housed in the College Library at Millbank, and then moved to the Muniments Room in the Corps Museum at Keogh Barracks, Aldershot. The Collection has recently been deposited on permanent loan for safe keeping and cataloguing in the Library of the Wellcome Institute for the History of Medicine, in Euston Road, London, where it is available for consultation (166). Besides Captain Kennedy's thesis on Malta Fever and other memorabilia of the Mediterranean Fever Commission, of particular interest is Bruce's own collection of lantern slides taken by himself and his wife, from which several of the illustrations in this article have been taken.

c. David Bruce Lectures. Since 1982, the Department of General Practice at Millbank has honoured Sir David Bruce, who worked for two years as a general practitioner in Reigate before joining the Army, through a series of annual 'David Bruce Lectures' by eminent General Practitioners. Three of these lectures have been published in the Corps Journal, describing the Evolution of General Practice in the British Army (167), Research (168), and Audit (169). These illustrate how far General Practice in the British Army has evolved since the early 1960 s, such that it is now a specialty on a par with medicine and surgery, with a professor of General
Practice at the College, a flourishing Department, and first-rate vocational training schemes. This shows "what can be achieved with sound sense, perseverance ${ }_{k}^{3}$ perspiration, application, demonstration andz inspiration" (167), these being the same characteristic $\mathbb{\AA}$ of, and the same principles followed by, David Bruce? and thus is a true example of Bruce's continuing legacy te्त the Royal Army Medical Corps.

\section{Acknowledgement}

I am indebted to my father, Dr Luis Vassallo MD FRCP, whose encouragement and enthusiasm for the history of brucellosis has enkindled in me a similar interest.

\section{REFERENCES}

Up to 1903 ...

1. MARSTON J A. "Report on Fever (Malta)", Army Medi $\overrightarrow{\vec{\omega}}$ cal Department Medical Report for 1861, London, $1863 ;$ ब 3:520-521.

2. VEALE H. Report on the Cases of Fever from Cyprus, Malta and Gibraltar, that were treated in the Medical Division of the Royal Victoria Hospital, Netley during the year 1879." Army Medical Department Medical Report, London. 1881;21:260-276.

3. BRUCE D. "Note on the Discovery of a Micro-organismincw Malta Fever"'. Practitioner, 1887; 39:161-170.

4. BRUCE D. "The Micrococcus of Malta Fever." Pras. tioner, 1888; 40:241-249.

5. BRUCE D. "On the Etiology of Malta Fever." Arm Medical Department Medical Report, London, 1892; 우: 365-370. 6. HUGHES M L. "Mediterranean, Malta, or Undul
Fever." Macmillan and Co. 1897 .

7. WrIGHT A E. "Note on the Technique of Sersi Diagnosis of Acute Specific Fevers." Br Med $J$ 1897 139.

8. WRIGHT A E, SEMPLE D. "On the Employment of De Bacteria in the Serum Diagnosis of Typhoid and MaE्F Fever." BrMed J1897; 1:1214-1215.

Prologue

9. CRAWFORD-KENNEDY J. "Notes on a case of chronico synovitis, or bursitis, due to the organism of Mediterra-Q nean Fever." J R Army Med Corps 1904; 2: 178-180.

10. BRUCE D. "Malta Fever" (Editorial). J $R$ Army Med Corps $1904 ; 2: 485-502$.

11. BRUCE D. "Malta Fever" (Editorial). J R Army Med? Corps 1904; 2:603-605.

12. BRUCE D. "Malta Fever, Part II" (Editorial), $J$ R Army Med Corps 1904; 2:731-736.

13. Principal Medical Officer, Malta (Wolseley W O). "Notes from Malta," J R Army Med Corps 1904; 2 (Corps News) 641.

14. GLENN ALLEN S. "Some observations on an outbreak of Mediterranean Fever in Malta last year, with special reference to the 'Air-Borne' theory of conveyance of the infection." J R Army Med Corps 1904; 2:699-704.

15. GRAY W L. "Notes from Malta." J R Army Med Corps 1904; 2 :(Corps News) 756.

16. CRAWFORD KENNEDY J. "Notes from Malta". J R Army

Med Corps $1905 ; 4$ : (Corps News) 29 .
17. BRUCE D. "Review of Research Work done by the RoyaP Army Medical Corps in 1904"' (Editorial). J R Army Med Corps $1905 ;$ 4:219-221.

18. CRAWFORD KENNEDY J. "A case of double and simulta neous infection by the organisms of enteric and of Malta Fever". JR Army Med Corps 1905; 4:364-368.
. 
19. Crawford Kennedy J. "Malta Fever in the Military Hospital, Valletta, Malta, during the years 1897 to 1904". JR Army Med Corps 1905; 4:634-646.

20. MANGIN F M. "Malta Fever in England”. J R Army Med Corps 1904; 2:729-730.

MFC

21. Reports of the commission for the Investigation of Mediterranean Fever, Parts i-vii, London 1904-1907.

22. Mediterranean Fever Commission (MFC) "Introduction". JR Army Med Corps 1905; 5:77-78.

23. (MFC) HoRROCKS W H. "Report I: On the duration of life of the Micrococcus melitensis outside the human body', JR Army Med Corps 1905; 5:78-87.

24. (MFC) HorRoCKS W H. "Report II: Further studies on the saprophytic existence of Micrococcus melitensis', $J R$ Army Med Corps 1905; 5:87-94.

25. (MFC) HoRROCKS W H. "Report III: On the recovery of the Micrococcus melitensis from the urine, faeces and sweat of patients suffering from Mediterranean Fever". $J$ $R$ Army Med Corps 1905; 5:171-195.

26. (MFC) HORROCKS W H. "Report IV: Experiments on the mode of conveyance of the Micrococcus melitensis to healthy animals". JR Army Med Corps 1905; 5:31 1-340.

27. (MFC) GILmOUR R T. "Report V: Description of a method of cultivating the Micrococcus melitensis from small quantities of peripheral blood and inoculation experiments with the micro-organisms isolated." J R Army Med Corps 1905; 5: 435-448.

28. (MFC) ZAMMIT T. "Report VI: Isolation of the Micrococcus melitensis from the blood'. J R Army Med Corps $1905 ; 5: 449-456$.

29. (MFC) SHAW E A. "Report VII: Interim Report of experimental work in the investigation of Mediterranean Fever, dealing with blood, skin, sweat, filtrations, aggultinating serum, and various inoculations on different animals"'. JR Army Med Corps 1905; 5:456-471.

30. (MFC) HORROCKS W H, CRAWFORD KENNEDY J. "Goats as a means of propagation of Mediterranean Fever' $J R$ Army Med Corps 1906; 6:381-402.

31. (MFC) HoRrocks W H, CRAWFord KenNEdy J. "Mosquitoes as a means of dissemination of Mediterranean Fever"'. JR Army Med Corps 1906; 6:487-500.

32. (MFC) CRAWFORD KENNEDY J. "Examination of animals in connection with Mediterranean Fever" $J R$ Army Med Corps 1906; 6:500-506.

33. (MFC) CRAWFORD KENNEDY J. "Bacteriological examinations of cases of Mediterranean Fever". JR Army Med Corps 1906; 6:623-627.

34 (MFC) ZAMMIT T. "An examination of goats in Malta, with a view to ascertain to what extent they are infected with Mediterranean Fever"'. JR Army Med Corps 1906; 6: 627-632.

35. (MFC) HoRROCKS W H. "Contact Experiments". $J R$ Army Med Corps 1906; 6:632-637.

36. (MFC) SHAw E A. "Mediterranean Fever in Goats, Cows and other animals"'. JR Army Med Corps 1906; 7:1-12.

37. (MFC) BASSETT-SMITH P W. "A critical examination of the blood of patients in hospital, to determine if other than Mediterranean Fever sera would agglutinate the $M$. melitensis". J R Army Med Corps 1906; 7:13-16.

38. (MFC) DAviES A M. "Report on the Prevalence of Mediterranean Fever amongst British Troops in Malta, 1905'. JR Army Med Corps 1906; 7:93-115.

39. (MFC) DAVIES A M. "Report on the Prevalence of Mediterranean Fever amongst British Troops in Malta, 1905. Section II". JR Army Med Corps 1906; 7:245-254.

40. (MFC) DAvieS A M. "Report on the Prevalence of Mediterranean Fever amongst British Troops in Malta, 1905 (continued)". J R Army Med Corps 1906; 7:307-321.

41. (MFC) DAviES A M. "Report on the Prevalence of Mediterranean Fever amongst British Troops in Malta, 1905 (continued)". JR Army Med Corps 1906; 7:419-440. C

42. (MFC) DAVIES A M. "Report on the Prevalence of Mediterranean Fever amongst British Troops in Malta, $1905 \frac{2}{2}$ (continued)"'. JR Army Med Corps 1906; 7:547-567.

43. (MFC) HORROCKS W H. "Mediterranean Fever in Gibraltar”'. JR Army Med Corps 1907; 8:374-384.

Entomology

44. Ross, E H, MuRRay LEVICK G. "Experiments on the transmission of Mediterranean Fever'. $J R$ Army Med Corps 1905; 5:240-247.

45. Ross, E H, MURRAY LEVICK G. "Notes on some of the Blood-sucking insects of the Mediterranean littoral". $J R$ Army Med Corps 1905; 5:385-390.

Serendipity

46 (MFC) ZAMMIT T. "A Preliminary Note on the $\frac{\bar{\rho}}{\supset}$ susceptibility of goats to Malta Fever". J $R$ Army Med Corps 1905; 5:341-342.

47 (MFC) HORROCKS W H. "Preliminary Note on Goats as a" means of Propagation of Mediterranean Fever". J R Army $\overrightarrow{0}$ Med Corps 1905; 5:343-350.

Controversy

48 Ross E H, MurRay LeVICK G. "Dissemination of Malta Fever by Goats' Milk" (Correspondence). J R Army Med Corps 1905; 5:662.

49 KENNEDY J C. "Notes from Malta". J R Army Med Corps 1905; 5 :(Corps News) 44.

50 KENNEDY J C. "Notes from Malta". J $R$ Army Med Corps 1906; 6:(Corps News) 132.

51 ANONYMOUS "Notes from Malta". J R Army Med Co 1906; 7:(Corps News) 7.

Requiem

52 KENNEDY J C. "Notes from Malta". J R Army Meds Corps 1905; 5: (Corps News) 4.

53 ANONYMOUS "Deaths". J R Army Med Corps 1905; (Corps News) 11.

53A RAMC FUND "Memorial to the late Colonel W $\overparen{D}$ 응 Wolseley"'. J R Army Med Corps 1905; 5:(Corps News)足 94.

54 KENNEDy J C. "Notes from Malta", J $R$ Army Medo Corps 1905; 5:(Corps News) 106.

55 ANONYMOUS "The late Colonel W O Wolseley, RAMC JR Army Med Corps 1906; 6:(Corps News) 71.

56 POLLOCK C. "Notes from Malta". JR Army Med Co 1907; 8:(Corps News) 62-63.

S.S. Joshua Nicholson

57 ARMAND RUFFER N. "The possible infection of man with Micrococcus melitensis by goats' milk", (Correspondence). JR Army Med Corps 1906; 6:113.

58 KENNEDY J C. (Correspondence). J R Army Med Corps马 1906; 6:113-114.

59 GotSCHLICH E. (Correspondence). J R Army Med Corps 1906; 6:114-116.

60 BRUCE D. (Editorial). J R Army Med Corps 1906; 6:165167.

61 BRUCE D. "Malta Fever"' (Editorial). J R Army Med? Corps 1906; 6:330-352.

62 HORROCKS W H. "The possible infection of man with Malta Fever by Goats' Milk" (Correspondence). J R Army Med Corps 1906; 6:380.

63 CLAYTON F H A. "A more complete history of the outbreak of Mediterranean Fever on board the S.S. Joshua Nicholson Reports of the Commission for the? Investigation of Mediterranean Fever. Part VII, London 3 $1907 ; 107-121$

64 SCOTT H H. "Undulant Fever". In: SCOTT H H. "A음 History of Tropical Medicine" London: Edward Arnold, $1939 ; 768-780$

Victory

65 BRUCE D. "Recent researches into the epidemiology of Malta Fever". J R Army Med Corps 1907; 8:225-235. 
66 BASSETT-SMITH P W. "A summary of recent work on the cause, prevention and treatment of Mediterranean or Undulant Fever, with some notes on the pathology". $J R$ Army Med Corps 1908; 10:1-13.

67 THORBURN W. "Two years of war surgery in Malta and the Mediterranean". JR Army Med Corps 1918; 31:106123.

68 BARNES S. "Why Malta" Malta: Publishers Enterprises Group, 1987.

69 CASSAR P. "Brucellosis", in CASSAR P: "Medical History of Malta"' Wellcome, London 1964; 240-247.

70 ANONYMOUS "The Government and Malta Fever" (Question in the House of Commons). J R Army Med Corps 1908; 10:(Corps News) 80-81.

71 HoRRoCKS W H. (On the Resignation of Colonel (now Sir David) Bruce) (Editorial). J R Army Med Corps 1908; 11: 70.

72 Pollock C E. “Notes from Malta”. J $R$ Army Med Corps 1906; 7(Corps News) 139-141.

73 ANONYMOUS "Edinburgh University Graduation Ceremonial"', J $R$ Army Med Corps 1908; 11:(Corps News) 142.

74 ANONYMOUS "Royal Army Medical Corps Ball at the Valletta Hospital"'. The Daily Malta Chronicle, 13 March $1909 ; 8-9$.

75 STANLEY R. "Notes from Malta". J R Army Med Corps 1909; 12:(Corps News) 112-114.

\section{Epidemiology}

76. CRAWFORD KENNEDY J. "The Incidence of Malta Fever amongst those employed in the Military Hospital, Valletta, during the year 1905', J R Army Med Corps 1906; 6:408-422.

77 StathaM J C B. "Notes on an investigation into the blood in cases of tubercular disease and Malta Fever', $J R$ Army Med Corps 1906; 6:512-523.

78 SHAW E A. "The ambulatory type of case in Mediterranean or Malta Fever". J $R$ Army Med Corps 1906; 6:638-645.

79 BouSFIELD L. "A case of Malta Fever with ulceration of the small intestine". $J R$ Army Med Corps 1906; 7:174177.

80 BOUSFIELD L. "Some remarks on protective inoculation against Malta Fever"'. J R Army Med Corps 1906; 7:179182.

81 EYRE J W H. "Some observations on the morphology and biology of Micrococcus melitensis"'. JR Army Med Corps 1907; 8:113-122.

82 CREE G. "Recurrence of Malta Fever". J R Army Med Corps $1907 ; 8: 634$.

83 Pollock C E. "Notes from Malta". J $R$ Army Med Corps 1907; 8:(Corps News) 85.

84 WILliaMS E M. "Mediterranean Fever: Infection in Utero"'. JR Army Med Corps 1907; 9:59-60.

85 HoLT M P. "Malta Fever" (Correspondence). J R Army Med Corps 1907; 9:546.

86 MacNEECE J G. "Fleet-Surgeon Bassett-Smith and Malta Fever" (Correspondence). J R Army Med Corps 1908; 10: 215-216.

87 BARNETT WILSON J. "Malta Fever"' (Correspondence). $J$ $R$ Army Med Corps 1908; 10:216-217.

88 ZAMMIT T. "Report on the goats ill with Mediterranean Fever bought in April 1906, and on the kids born of some of them at the Lazaretto". J R Army Med Corps 1908; 10: 219-225.

89 SAMUT R. "Paratyphoid infection during the course of Mediterranean Fever"'. J R Army Med Corps 1908; 11: 302-304.

90 McNaught J G. "Malta Fever and Simple Continued Fever: the serum reaction and retrospective diagnosis". $J$ $R$ Army Med Corps 1909; 12:415-417.

91 GERRARD J J. "Further notes on fevers in Malta". $J R$ Army Med Corps 1909; 13:18-32.
92 SAMUT R. "Paratyphoid simulating Malta Fever", $J R$ Army Med Corps 1909; 13:297-299.

93 GERRARD J J. "Further notes on fevers in Malta". $J R$ Army Med Corps 1909; 13:390-399.

94 PRYNNE H V. "Case of Mediterranean Fever treated with Vaccines". JR Army Med Corps 1910; 15:591-593.

95 SAMUT R. "Landry's Paralysis and Malta Fever". $J R \stackrel{\varnothing}{\varnothing}$ Army Med Corps 1911; 16:77-78.

96 Ross E H. "The prevalence of Mediterranean Fever in $\mathrm{O}$ Port Said"'. JR Army Med Corps 1906; 6:33-41.

97 Ross E H, "The elimination of Malta Fever from Port : Said". J R Army Med Corps 1911; 16:618-624.

98 BIRT C. "Mediterranean Fever in South Africa", $J R \stackrel{\text { क्? }}{+}$ Army Med Corps 1906; 6:1-5.

99 STRACHAN P D. "Undulant Fever in South Africa'". $J R$ 으 Army Med Corps 1907; 9:83-97.

100 STRACHAN P D, BIRT C. "Malta Fever in South Africa". JR Army Med Corps 1909; 13:153-165.

101 BRUCE D, HAMERTON A E, BATEMAN H R, and MACKIE F P. “" 'Muhinyo', A Disease of Natives in Uganda". $J R \rightarrow$ Army Med Corps 1910; 15:527-532.

102 HORROCKS W H. "Notes of cases of Mediterranean Fever $\rightarrow$ occuring in Gibraltar during 1906". J R Army Med Corps $\vec{\omega}$ $1907 ; 8: 426-428$.

103 FOWLER C E P. "Mediterranean Fever in Gibraltar in 1909'. . J R Army Med Corps 1910; 15:54-62.

104 McNAUGHT J G. "Malta Fever in the Orange River? Colony" (Correspondence). J R Army Med Corps 1908; $\vec{\omega}$ 10:113.

105 SIMPSON R J S. "Malta Fever from the Blue Nile", $J R$ 仓 Army Med Corps 1908; 11:593-596.

106 BOUSFIELD L. "Malta Fever in the Sudan". J $R$ Ar依 Med Corps 1908; 11:596-599.

107 CRAWFORD KENNEDY J. "Malta Fever in the Sudan", (Correspondence). J R Army Med Corps 1909; 12:24;242.

108 KENNEDY J C. "Vaccine treatment of Malta Fever", J级号 Army Med Corps 1910; 15:317-320.

"Poor Maltese Goat! ...

109 CRAWFORD KENNEDY J. "A little humour from the Malfa $\overrightarrow{0}$ Fever Commission". J R Army Med Corps 1907; 9:5क्षी 598.

110 Pollock C E. "Notes from Malta". J R Army Med Co 1907; 9:(Corps News) 95-96.

111 CASSAR P. "Sir Themistocles Zammit and the Controversy on the Goat's Role in the Transmission of Brucellosis (Mediterranean Fever) 1909-1916" Malta:음 Information Division, Malta Govt., 1981.

112 B E K. "Bruce and the Microbe" Malta: Risorgimento, $4 \overrightarrow{\vec{F}}$ Aug 1910, 2.

Cows...

113 KENNEDY J C. "Preliminary note on the presence of agglutinins for the Micrococcus melitensis in the milk and? blood-serum of cows in London"'. $J R$ Army Med Corps $1914 ; 22: 9-14$

114 CUMmins S L, Coppinger C J, URQuhart A L, "Further observations on the presence of antibodies for Micrococcus melitensis in the milk of English cows". $J R_{\bar{\Phi}}^{-}$ Army Med Corps 1914; 23:36-41.

115 HORROCKS W H. "The relation of Mediterranean Fever to contagious abortion in cattle" (Editorial). J R Army Medo Corps $1927 ; 49: 107-115$.

116 WIGMORE J B A. "Note upon the production of Brucellaci agglutinins". IR Army Med Corps 1930; 54:5-10.

117 AUSTIN F C K. "A case of Brucella abortus infection". $J R$ Army Med Corps 1930; 54:46-50.

118 HoRROCKS W H. "Undulant Fever" (Editorial). J R Army? Med Corps 1938; 71:332-336.

Literature

119 FORSTER. "Distribution of Malta Fever" (Review). $J R N$ Army Med Corps 1906; 6:378. 
120 Shaw E A. "La Fievre Mediterranneenne en Tunisie" (Book review). JR Army Med Corps 1906; 7:84-85.

121 BASSETT-SMITH P W. "The treatment of Mediterranean Fever by means of vaccines, with illustrative cases" (Abstract). JR Army Med Corps 1907; 9:317.

122 Fortescue A I. "Malta Fever in Algeria" (Review). $J R$ Army Med Corps 1908; 10:454.

123 McNEECE J G. i. "Studies in Mediterranean Fever in the Village of Kleber (Oran) in 1907" (Review). ii. "Studies on Mediterranean Fever in 1907" (Review). iii. "Studies on Mediterranean Fever in goats in Algiers in 1907" (Review). JR Army Med Corps 1908; 11:215-217.

124 FowLER C E P. "Malta Fever at Marseilles" (Review). $J R$ Army Med Corps 1910; 15:762.

125 WILSON G S. "The diagnosis, aetiology and prophylaxis of Brucella melitensis infections in animals" (Review). $J R$ Army Med Corps 1935; 65:67-68.

126 BIRT C. "Treatment of Mediterranean fever with Collargol"' (Review). JR Army Med Corps 1906; 7:416.

127 ORPEN L J J. "A method of blood culture in Undulant (Malta) Fever and other diseases" (Abstract). $J R$ Army Med Corps 1923; 41:396.

128 WILSON G S. "Methods of differentiating organisms of the Brucella group" (Review). J R Army Med Corps 1932; 59:391.

129 FORTESCUE A I. " La Febbre Mediterranea (Setticemia del Bruce)' (Book Review). J R Army Med Corps 1908; 10: 448.

$130 \mathrm{McN} J$ E. "On Malta Fever in German South-West Africa" (Review). JR Army Med Corps 1909; 13:610-611.

131 LOVELL R. "Brucella melitensis Infection in the Maltese Goat"' (Review). JR Army Med Corps 1940; 75:338-339.

132 WILSON G S. "The influence of Tuberculosis upon the development of Brucella abortus infection" (Review). $J R$ Army Med Corps 1937; 68:211-212.

133 Rolleston J D. Reviews: i. THOMPSON T. "Bacillus abortus infection in man". ii. HARRISON H, WILSON G S. "The possible existence in this country of disease due to infection with Brucella abortus", iii. CLARK T. "Sur la fievre ondulante aux Etats-Unis". iv. MADSEN T. "La fievre ondulante a B.abortus du Danemark". v. KLING C. "La fievre ondulante en Suede" J $R$ Army Med Corps 1929; 53:232-235.

134 WILSON G S. "The excretion of Brucella abortus in cow's milk" (Review). JR Army Med Corps 1933; 60:465-466.

135 ANONYMOUS. "Discussion on Undulant Fever" (Review). JR Army Med Corps 1933; 61:233-235.

136 WILSON G S. (Reviews): i. "Undulant Fever in New York State". ii. "The intradermal reaction in the diagnosis of brucella infections". iii. "The distribution of Brucella abortus in the infected udder", J $R$ Army Med Corps $1934 ; 63: 414-415$.

137 MAcFarlane R G. "Brucellosis. An account of three cases treated with Chloromycetin and Aureomycin"'. $J R$ Army Med Corps 1952; 98:144-148.

138 MONTGOMERY R. "A case of Brucellosis with neurological complications"'. JR Army Med Corps 1956; 102:82-83.

139 SCOTT H H. "A History of Tropical Medicine". J R Army Med Corps 1940; 74:306-310.

Obituaries

140 THOMPSON H N. "The late Major J C Weir" (Obituary). $J R$ Army Med Corps 1910; 14:(Corps News) 32-33.

141 HoRRoCKS W H. "Major-General Sir David Bruce KCB, LLD, DSc, FRCP, FRS" (Obituary). $J R$ Army Med Corps 1932; 58:1-4.

142 AUSTEN E E. "Obituary of the late Major-General Sir David Bruce" (Correspondence). J R Army Med Corps 1932; 58:237.

143 LYLE CUMMins S. "The late Colonel Sir William Heaton
Horrocks, KCMG, CB, AMS - Editor of the "Journal of 7 the Royal Army Medical Corps' 1908-1940" (Obituary). $J$ R Army Med Corps 1941; 77:2-6.

Memorials

144 ANONYMOUS "Renaming of Hospital". J $R$ Army Med Corps 1951;97:65.

145 SACHS A. "A Memorial to Major-General Sir David Bruce KCB, FRS. Introducing the David Bruce O Laboratories". JR Army Med Corps 1951; 97:293-295.

146 NoBLE J E. "The David Bruce Laboratories 25th" Anniversary"'. $J R$ Army Med Corps 1967; 113:208-212.

147 PERKINS H N. (Correspondence). J R Army Med Corps $\stackrel{6}{+}$ 1968; 114:54

148 BRUCE M. "Life in Ladysmith" (Correspondence). $J R \bar{\sigma}$ Army Med Corps 1956; 102:153-154.

149 McCLINTOCK C. "The David Bruce Royal Naval Hospital, $\underset{\mathrm{Q}}{\overrightarrow{\mathrm{Q}}}$ Malta". JR Nav Med Serv 1971; 57:49-50.

150 CASSAR P. "Sir Temi Zammit's Laboratory" Malta: پ Department of Health, 1980.

Centenary

151 HARRIS F "Foreword", JR Army Med Corps 1955; 101: 79-80.

152 TULlOCH W J. "Sir David Bruce. An Appreciation". $J R$ Army Med Corps 1955; 101:81-90.

153 ROBERTSON M. "Sir David Bruce: An appreciation of the 3 man and his work', J R Army Med Corps 1955; 101:91-? 99.

154 SACHS A. "The Centenary of British Military $\infty$ Pathology"'. JR Army Med Corps 1955; 101:100-121.

155 DAVIES M. "A Bibliography of the work of Sir Dared Bruce, 1887-1924", J R Army Med Corps 1955; 101:128129.

156 NEAL J B. “Sir David Bruce 1855-1931" (Editorial). $j_{B}$ 을 Army Med Corps 1955; 101:159-161.

Bibliography

"A bibliography of the work of Sir Willia Heaton Horrocks (1859-1941)", J R Army Med Coras 1964; 110:156-162.

158 Hughes G W G, Hughes M H. i. "Matthew Loư⿱s $\overrightarrow{0}$ Hughes and Undulant Fever", ii. "Matthew Lo@s Hughes-Bibliography". J R Army Med Corps 1969; 13: 198-203.

Philately

159 ANONYMOUS. "Anti-Brucellosis Congress", $\mathrm{Br} \mathrm{Med} J$ $1964 ;$ i: 1194

160 BAIRD J P. "Malta Fever" (Editorial). J $R$ Army Med응 Corps 1965; 111:164-165.

Vella

161 Vella E E "Drew Roll" (Correspondence). J R Army Med Corps 1972;118:182-183.

162 Vella E E, GOODE D. "Holiday Brucellosis"'. J R Army 㐏 Med Corps 1973; 119:34-39.

163 Vella E E. "Major-General Sir David Bruce, KCB" $J R$ Army Med Corps 1973; 119:131-144.

164 Vella E E. "Brucellosis (The Corps Disease)". J R Army Med Corps 1983; 129:97-100.

165 Vella E E. "The (British) Army Medical Service and Malta Fever". Milit Med 1963; 128:1076-1090.

Muniment Collection

166 "Historical Records of the Royal Army Medical Corps". JR Army Med Corps 1992; 138:54.

Lectures

167 FRY J. "First David Bruce Lecture in the David Bruce Tradition: The Evolution of General Practice in the $\mathrm{O}$ British Army". JR Army Med Corps 1982; 128:152-159.

168 MorRell D C. "Sir David Bruce Memorial LectureO 1988'. JR Army Med Corps 1989; 135:43-48.

169 CARNE S J. "Sir David Bruce Lecture 1990: Heads and Tales". JR Army Med Corps 1991; 137:63-68. 